\title{
The effect of mazindol on growth hormone secretion in boys with Duchenne muscular dystrophy
}

\author{
J H COAKLEY, J MOORCRAFT, * L J HIPKIN, $\dagger$ C S SMITH, ${ }^{*}$ R D GRIFFITHS, \\ R H T EDWARDS \\ From the Muscle Research Centre, University Department of Medicine, Royal Liverpool Hospital, and the \\ Department of Child Health, ${ }^{*}$ and Sub-department of Endocrine Pathology, $\dagger$ Royal Liverpool Children's \\ Hospital (Alder Hey), Liverpool, UK
}

SUMMARY Mazindol has been reported to improve muscle function in Duchenne muscular dystrophy (DMD) by virtue of its growth hormone (GH) suppression. The effects were studied on GH secretion (in response to growth hormone releasing factor and sleep) of mazindol 2 mg daily for 3 months in five boys with DMD. No consistent change was found following mazindol therapy. Adverse effects were noted in all the boys which may preclude long term use of mazindol in DMD.

Duchenne muscular dystrophy (DMD) is a progressive degenerative $\mathrm{X}$-linked disorder of muscle causing impaired motor function and culminating in death in the late teens or early twenties, frequently from respiratory failure. There is no cure for the disease, and despite advances in orthopaedic care and physiotherapy, the mean age at death is essentially unaltered from the time of Duchenne's description of the condition in the mid nineteenth century. ${ }^{1}$

Mazindol has been proposed as a potential therapeutic agent in DMD on the basis of two trials. ${ }^{23}$ Mazindol is a non-amphetamine appetite suppressant licensed in the UK for the short term treatment of morbid obesity; it is not recommended for patients under 16 years of age. ${ }^{4} \mathrm{Zatz}$ and co-workers suggest that mazindol has a beneficial effect on skeletal muscle function in DMD. ${ }^{2}$ In a double blind placebo-controlled trial of mazindol administered to identical twins with DMD over a 12 month period, the rate of deterioration was slower in the boy treated with active drug compared with his brother who received placebo. A previous open trial of mazindol in nine boys with DMD had shown no beneficial effect, although the boys studied formed a heterogeneous group with respect to age and physical condition, and it is possible that such an effect was missed. ${ }^{3}$ The putative action of mazindol in DMD is growth hormone (GH) inhibition.

Address for reprint requests: Prof R H T Edwards, Muscle Research Centre, Royal Liverpool Hospital, PO Box 147, Liverpool L69 3BX, UK.

Received 10 May 1988

Accepted 1 July 1988
It has been reported that growth hormone (GH) may have a harmful effect on the muscles in DMD. The evidence for this has been produced by three groups of workers. Chyatte has shown that exogenous GH administration produced negative nitrogen balance in boys with DMD in contrast to its anabolic effect in control subjects and patients with myotonic dystrophy, but as this was only a short term metabolic balance study it was not possible to draw firm conclusions about the clinical effect on muscle function. ${ }^{5}$ Zatz described a young boy with DMD and coincidental congenital GH deficiency. ${ }^{6}$ He showed an attenuated decline in motor performance compared with the usual course of deterioration in DMD and to the pattern of deterioration in other members of the family with DMD but without GH deficiency.

Studies in dystrophic mice have provided further support for the theory that growth, or more likely a disproportionate bone growth compared with muscle growth, plays a role in the pathogenesis of muscular dystrophy, showing that those mice exhibiting concurrent congenital dwarfism have a less severe dystrophy than non-drawf mice.

In view of the potentially harmful effects of $\mathrm{GH}$ on dystrophic muscle it has been suggested that $\mathrm{GH}$ inhibitors should be used in further clinical trials of patients with DMD, and mazindol has been proposed as a suitable agent. $^{2}$ Collipp also suggested that mazindol therapy may be associated with an increased tissue selenium content. ${ }^{3}$

The evidence that mazindol is a $\mathbf{G H}$ suppressor is not universally accepted, with one study suggesting that mazindol administered to obese children has a 
suppressing effect, ${ }^{8}$ but another, again in obese children, reporting that mazindol has no effect on GH secretion.' There has been one publication showing a definite, but slight, increase in plasma levels of $\mathbf{G H}$ following mazindol administration to healthy volunteers. ${ }^{10}$ There is therefore some doubt about the effectiveness of mazindol as a GH suppressant.

Double-blind multicentre trials are now taking place in the USA which will study mainly the functional response of patients with DMD during prolonged mazindol therapy (M H Brooke, personal communication). The major problem with a formal therapeutic trial of any agent in DMD is that because of the slow and variable decline in muscle function, a large number of boys has to be studied over a long period to ensure that misleading conclusions are not drawn. Such trials have been carried out in the USA ${ }^{11}$ and Europe, ${ }^{12}$ but the cost is great both financially and in terms of the commitment of the patients and investigators. We have advocated a different approach in which short metabolic studies enable us to characterise the mode of action of a putative therapeutic agent so that a rational decision may then be taken about the likelihood that a long term trial will be worth undertaking. ${ }^{13}$ Our study was therefore designed to assess the effect of short-term mazindol (Teronac, Sandoz) treatment on the pattern of GH secretion in the physiological setting of stage IV sleep and following the administration of GH releasing factor (GRF, Kabivitrum). In addition to the studies of GH secrection we measured plasma prolactin concentrations, since this hormone is secreted from the anterior pituitary gland and is closely related structurally to GH. ${ }^{14}$ In the light of Collipp's suggestion that mazindol increased tissue selenium content we also measured muscle glutathione peroxidase (GSHPx) activity in samples obtained by percutaneous biopsy ${ }^{15}$ since the only known role of selenium in humans is as a component of this enzyme. ${ }^{16}$ In view of the paucity of information about side effects in young boys we closely monitored any adverse reactions.

\section{Patients}

Five boys with DMD were studied. The mean age was 6.73 yr (range 5.83-7.50 yr). None of the boys was obese. The diagnosis of DMD was based on the characteristic history and findings on clinical examination together with raised plasma creatine kinase activity. In all cases a muscle biopsy had confirmed the presence of a dystrophic process. The boys had all been attending a muscle clinic with a particular interest in growth and development for at least one year.

The approval of Royal Liverpool Children's Hospital (Alder Hey) Ethical Committee was given for a 3 month trial in boys aged between 5 and 8 years of age with DMD. Signed informed consent was obtained from the parents.

\section{Methods}

The assessments took place before starting mazindol, and again after 3 months therapy with $2 \mathrm{mg}$ of mazindol taken orally once daily, the same as that used by $\mathrm{Zatz}^{2}$ and Collipp. ${ }^{3}$ When the boys were admitted to hospital a cannula was inserted into a vein at least 2 hours before any blood was taken for GH estimation and kept patent with heparin. During the first hospital night the electroencephlogram (EEG) was monitored continuously to allow accurate sleep staging. The baseline sample of blood for GH estimation was taken before the onset of sleep, and subsequent samples were removed during the first episode of stage IV sleep and then every 15 minutes until seven samples had been collected. After an overnight fast, GRF $100 \mu \mathrm{g}$ was injected via the indwelling cannular and blood samples were taken every 15 minutes for 2 hours. Blood was immediately spun down, plasma separated and stored at $-20^{\circ} \mathrm{C}$ until analysed for GH. The samples for each patient before and after mazindol therapy were analysed simultaneously to exclude the effects of inter-assay variation. Plasma $\mathrm{GH}$ was measured in duplicate by conventional radioimmunoassay (sensitivity $0.4 \mathrm{mU} / 1$, intra-assay coefficient of variation $10 \%$ ).

In addition to the studies of $\mathrm{GH}$ secretion we measured height, weight, quadriceps strength with a hand held myometer; time taken to run 10 metres, and resting and post10 metre run heart rate. Blood was also taken for plasma prolactin concentration and for serum muscle enzyme activities.

Samples of muscle were obtained by percutaneous biopsy under local anaesthesia from the anterior tibial muscle using the conchotome technique, ${ }^{15}$ frozen immediately in liquid nitrogen and subsequently analysed by the method of Beutler and colleagues ${ }^{17}$ for GSHPx activity.

\section{Results}

Unacceptable side effects necessitated the withdrawal of one patient from the study after only 2 months on mazindol. Initially he became tearful and depressed,

Table 1 Heart rate at rest and after exercise before and during mazindol therapy

\begin{tabular}{lllll}
\hline Patient & Pre & I month & 2 months & 3 months \\
\hline Resting & heart rate & & & \\
a & 108 & 132 & 140 & 104 \\
b & 108 & 120 & 124 & - \\
c & 100 & 112 & 108 & 108 \\
d & 88 & 108 & 100 & 101 \\
e & 100 & 120 & 112 & 120 \\
Mean & $100 \cdot 8$ & 118.4 & 116.8 & 108.3 \\
& & & & \\
Post exercise & $(10$ m run $)$ & heart rate & & \\
a & 124 & 148 & 156 & 160 \\
b & 142 & 136 & 144 & -132 \\
c & 124 & -120 & 144 \\
d & 104 & 136 & 120 & 145 \\
e & 116 & 144 & 132 & 145.3 \\
Mean & 122.0 & 141.0 & 134.4 & \\
\hline
\end{tabular}

Patient $\mathrm{c}$ had sprained his ankle before his second assessment and was unable to complete the run. Patient $b$ was withdrawn from the trial after 2 months, hence data are not available for the 3 month assessment. 

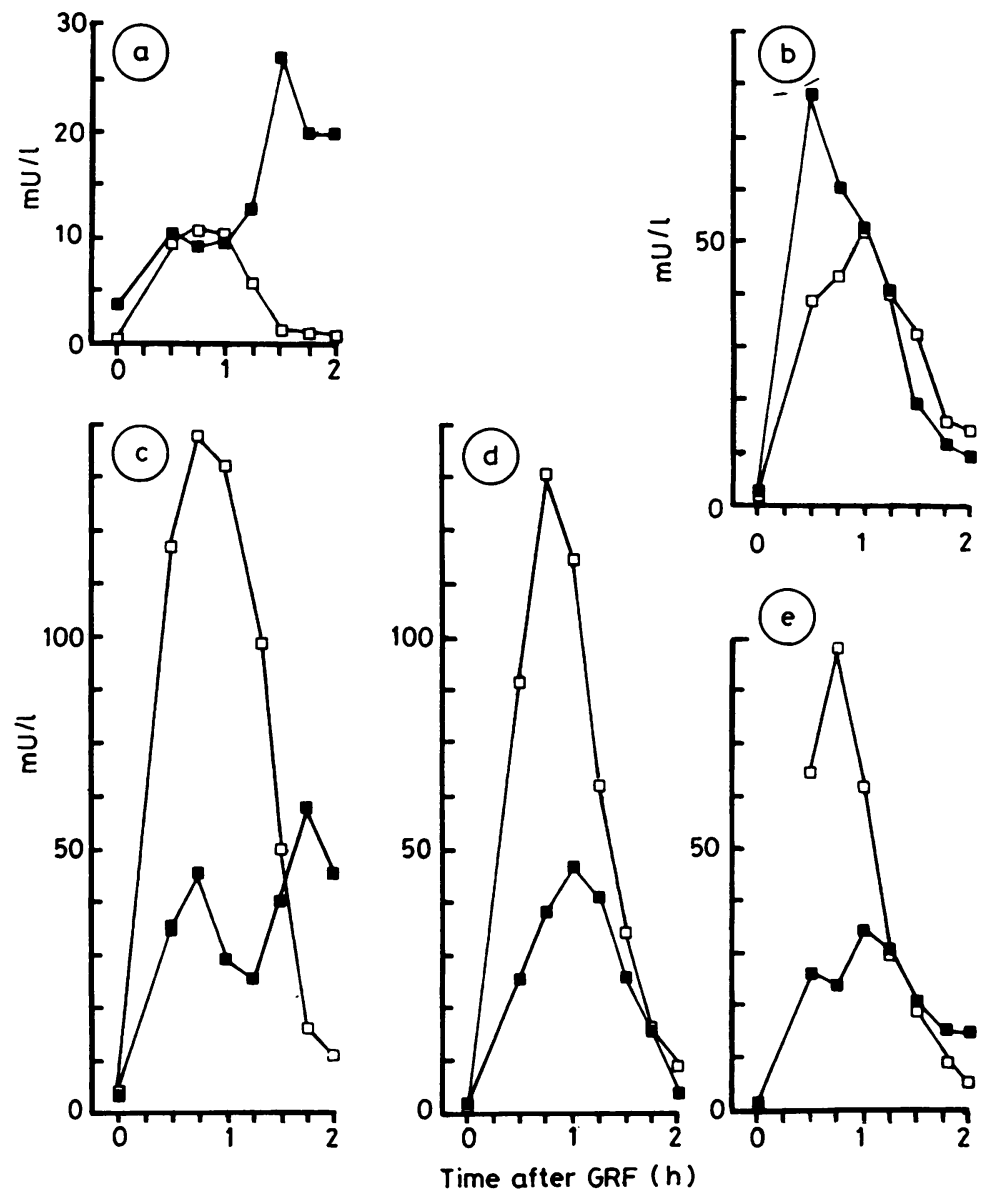

Time after GRF $(h)$

Fig 1 The growth hormone response to intravenous GRF $100 \mu \mathrm{g}$ before ( $\square$ ) and after (D) mazindol therapy. Note the different scales on the vertical axes. Growth hormone is shown on the vertical axis ( $m U / l)$, and time after injection of $G R F$ is on the horizontal axis. The patients are identified by the letters a-e.

and after 4 weeks of treatment, he became aggressive. Two months after the initiation of therapy he had been sent home from school on two occasions because of violent outbursts, with assaults on his teacher and fellow pupils. He was admitted for his follow up assessment immediately, while continuing on mazindol and withdrawn from the trial the next day. The other patients suffered side effects including irritability, sleep disturbances and in one case hallucinations but were able to complete 3 months treatment, most finding that by taking the tablets at night the unpleasant side-effects could be reduced.

One potentially serious adverse effect observed was an increase in both resting and post-exercise heart rate. The mean resting heart rate rose by $17.5 \%$ after one month on mazindol (see table 1), and although it fell slightly over the next 2 months it never returned to basal levels. The increase in heart rate following the 10 metre run (table 1) was also greater during mazindol therapy and did not alter during the study, post exercise heart rate increasing by a mean of $19 \%$ after 3 months. The electrocardiographic abnormalities characteristic of DMD were present in all the boys, and the appearances did not change during the study. These side effects have been reported to the Committee on Safety of Medicines.

Three patients showed a suppression of GH response to GRF following mazindol treatment, although in none of these did the GH increment fall below the normal response for adult men. ${ }^{18}$ The other two patients showed a slight increase in GH secretion following GRF (fig 1). The three patients who had 

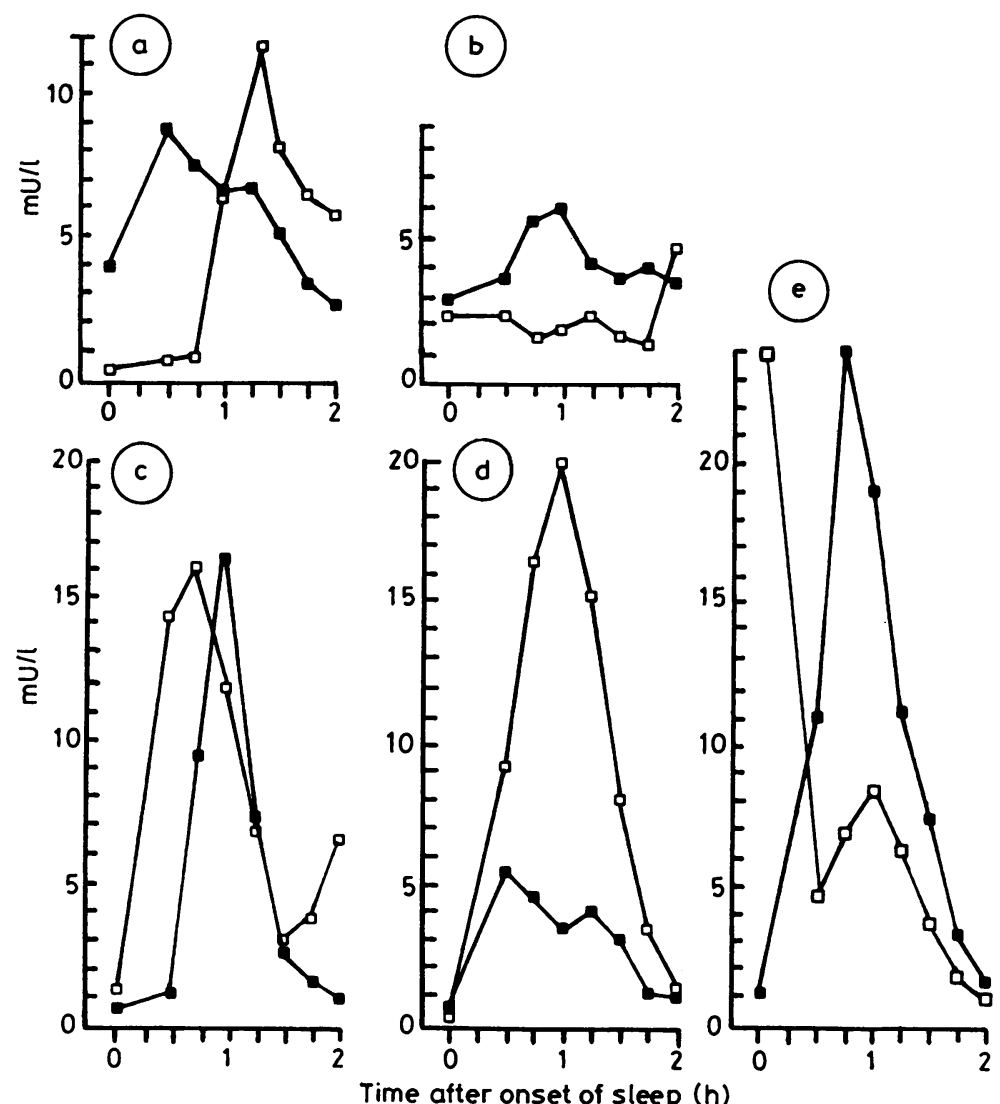

Fig 2 The growth hormone response to stage IV sleep before ( $\square$ ) and after ( $\square$ ) mazindol therapy. The growth hormone is shown on the vertical axis $(\mathrm{mU} / \mathrm{l})$, and time after the onset of sleep is on the horizontal axis. The patients are identified by the letters $a-e$.

suppression of $\mathrm{GH}$ response to GRF following mazindol showed different patterns of $\mathbf{G H}$ release during sleep (fig 2), two had no change and one showed suppression.

Of the two boys with increased $\mathrm{GH}$ response to GRF following mazindol therapy one showed a slight fall in sleep associated $\mathrm{GH}$ release and the other a slight increase.

One of the boys fulfilled our laboratory criteria for GH deficiency (peak GH concentration $<15 \mathrm{mU} / 1$ in two tests) before mazindol but not after, although at no time was there clinical evidence of GH deficiency.

No consistent effect on plasma prolactin concentration was noted during the course of the study, the mean values (range) being $206 \mathrm{mU} / 1(80-300)$ before treatment and $172 \mathrm{mU} / 1$ (130-240) after treatment.

The mean (standard deviation) muscle GSHPx activity prior to mazindol therapy was 2.48 (SD
0.79 ) $\mathrm{U} / \mathrm{g}$ soluble protein and after was 2.75 (SD $0.91) \mathrm{U} / \mathrm{g}$ soluble protein. There is no significant difference between the pre- and post-mazindol activity, and all the values are within our normal laboratory range for GSHPx. The changes in height and weight for four separate 3 month periods before and during mazindol therapy are shown in table 2. No effect of mazindol was seen on changes in height. There was an overall reduction in weight gain in the boys compared to the pre-treatment values, with three boys losing weight.

There were no significant changes in strength, motor ability or serum activities of muscle enzymes (see table 3).

\section{Discussion}

Our results suggest that mazindol does not have a 
Table 2 The effect of mazindol on changes in height and weight

\begin{tabular}{lcccc}
\hline \multicolumn{3}{c}{ Pre-mazindol } & & Mazindol \\
\cline { 2 - 5 } Patient & June 86- & $\begin{array}{l}\text { Sept 86- } \\
\text { San 87 86 }\end{array}$ & $\begin{array}{l}\text { Jan 87- } \\
\text { May 87 }\end{array}$ & $\begin{array}{l}\text { June 87- } \\
\text { Sept 87 }\end{array}$ \\
\hline Height & increase cm & & & \\
a & 1.9 & 2.4 & 2.3 & 1.7 \\
b & - & 1.0 & 1.8 & 1.5 \\
c & 0.5 & 1.8 & 1.8 & 2.1 \\
d & 2.5 & 1.7 & 1.8 & 1.3 \\
e & 2.3 & 2.0 & 0.6 & 2.5 \\
Mean & 1.8 & 1.78 & 1.66 & 1.8 \\
& & & & \\
Weight change & $(\mathrm{kg})$ & & & \\
a & 1.6 & -0.1 & 1.2 & -0.7 \\
b & -0.3 & 2.3 & 0.9 & -1.8 \\
c & 0.1 & 0.7 & 1.0 & 1.2 \\
d & 0.5 & 0.9 & 0.9 & -0.8 \\
e & 0.7 & 1.6 & -0.7 & 0.4 \\
Mean & 0.52 & 1.08 & 0.66 & 0.16 \\
\hline
\end{tabular}

Patient b's height was not measured on his first attendance (June 86) hence there are no data available for his height change over the first 3 month period.

consistent suppressive effect on GH release by laboratory criteria. Our study is in agreement with both of the previous trials of mazindol in DMD, ${ }^{23}$ that is the effect on height increase is not marked. The lack of a consistent effect on prolactin concentration, an anterior pituitary hormone which is structurally closely related to $\mathrm{GH},{ }^{14}$ suggests that mazindol does not have any significant influence on the function of the pituitary gland. It is not possible to say from such a short open study whether the drug has a clinically important beneficial effect on the course of the dystrophic process.

Mazindol is not recommended in the UK for treatment of patients under the age of 16 years, but we used the same dose regime as $\mathrm{Zatz}^{2}$ and Collipp ${ }^{3}$ for boys of approximately the age of our patients. Nevertheless the side effects of mazindol in the boys we studied were unacceptable to four of the families concerned and only one parent would have allowed a more prolonged trial. The side effects were to some extent predictable both from the Sandoz data sheet ${ }^{4}$ and from the trial reported by $\mathrm{Zatz}^{2}{ }^{2}$ although the severity was much greater than we had expected.

Should mazindol be shown to be of benefit in longer term trials, we feel that the side effects warrant serious reconsideration of the dose used in young patients, since even a fairly modest dose produces intolerable psychological reactions.

More disturbing than the psychological effects of mazindol was its effect on heart rate. The increase seemed not to be related directly to anxiety, since the severity of the psychological side effects did not correlate with the magnitude of the change in heart rate. Furthermore the increase in heart rate after exercise was also greater while taking mazindol, and it might be expected that anxiety would influence heart rate less after exercise than at rest. This adverse effect, previously undescribed in young boys with DMD treated with mazindol, may be of importance in view of the almost invariable co-existent cardiomyopathy in such patients. ${ }^{19}$ There has been one case report of a reversible cardiomyopathy in an obese adult treated with mazindol. ${ }^{20}$ The increase in heart rate may also explain the cardiomegaly seen in rats treated with mazindol in doses similar to those used in our patients with DMD (Coakley, Jackson, Wagenmakers and Edwards, 1988, unpublished data). Our finding of a weight decrease while taking mazindol suggests that a possible mechanism for improvement in dystrophy may be a decreased burden on already weakened muscles. It has previously been shown that weight reduction has significant benefits in functional performance in muscular dystrophy. ${ }^{21}$

The reason for the conflicting evidence about the effect of mazindol on $\mathbf{G H}$ release is not clear. It has been shown that mazindol administration produces a rise in plasma concentrations of $\mathbf{G H}$ in addition to several other pituitary hormones but this followed the administration of one dose of mazindol rather than a prolonged course of the drug, ${ }^{10}$ we have demonstrated in the rat that mazindol administration for 6 weeks leads to increased circulating $\mathrm{GH}$ concentrations (Coakley, Jackson, Wagenmakers, Ensor and Edwards, 1988, unpublished data). Eight days of a low calorie diet together with mazindol in the treatment of obese children has been shown not to suppress $\mathrm{GH}$, the assessment being based here on the peak $\mathbf{G H}$ response to arginine. ${ }^{9}$

The measurement of anterior pituitary function, particularly with respect to GH secretion is fraught with difficulties and many of the older tests are unreliable with false negative rates of up to $25 \%$ reported for insulin and clonidine induced $\mathbf{G H}$ release. $^{22}$ The authors of this report noted that many centres now employ at least two tests of $\mathrm{GH}$ release in

Table 3 Effect of mazindol on muscle function and serum markers of muscle damage

\begin{tabular}{lll}
\hline & Pre mazindol & Post mazindol \\
\hline 10 m (seconds) & $6 \cdot 1(5 \cdot 0-8 \cdot 0)$ & $5 \cdot 6(4 \cdot 5-7 \cdot 0)$ \\
QMVC (Newtons) & $66 \cdot 8(37 \cdot 0-100 \cdot 0)$ & $72 \cdot 8(47 \cdot 0-97 \cdot 0)$ \\
Creatine kinase & & \\
$\quad(U / 1)$ & $4648(4100-9960)$ & $7593(2615-13268)$ \\
Aldolase (U/1) & $39 \cdot 55(22 \cdot 1-57 \cdot 0)$ & $55 \cdot 73(23 \cdot 5-84 \cdot 0)$ \\
HBD (U/1) & $513(468-557)$ & $549(419-820)$
\end{tabular}

Results presented as mean (range).

$10 \mathrm{~m}$-the shortest time taken to cover 10 metres (best of 3 attempts).

QMVC - the maximum voluntary contraction of the quadriceps muscle (best of 3 attempts).

HBD - serum hydroxybutyrate dehydrogenase activity.

U/1-units per litre. 


\section{6}

view of the unreliable results obtained when only one is used. The data from the published reports of the use of mazindol in muscular dystrophy suggest a discrepancy between the clinical effect on growth and the effect on growth hormone secretion. Zatz studied the peak response of GH to levodopa administration in twins with muscular dystrophy and found a suppression to $5.8 \mathrm{ng} / \mathrm{ml}(11.6 \mathrm{mU} / \mathrm{l})$, compared with a pretreatment peak of $22.0 \mathrm{ng} / \mathrm{ml}(44.0 \mathrm{mU} / \mathrm{l}){ }^{2}$ The effect on growth was less marked; both children showed a slowed height gain, suggesting that there may have been another factor involved. The effect on weight in Zatz's trial was much more clear-cut, the child treated with active drug initially weighing $2.5 \mathrm{~kg}$ more than his twin brother who received placebo. At the end of the trial, the twin receiving active drug weighed $0.7 \mathrm{~kg}$ less than the placebo treated brother, and had lost a total of $1 \mathrm{~kg}$. The effect of fluctuation in weight of this order on muscle function in people with muscle diseases is not known, but there is no doubt that weight control plays a significant role in the preservation of overall muscle performance and that weight reduction may lead to an improvement in functional state. ${ }^{21}$

The effect of mazindol in Collipp's trial in muscular dystrophy was less marked in terms of functional changes in muscle. ${ }^{3}$ The effect on $\mathrm{GH}$ was assessed by comparing peak values in response to oral clonidine before and after mazindol therapy in nine boys. The mean peak value prior to mazindol was $8.6 \mathrm{ng} / \mathrm{ml}$ $(17.2 \mathrm{mU} / \mathrm{l})$, falling to $5.9 \mathrm{ng} / \mathrm{ml}(11.8 \mathrm{mU} / \mathrm{l})$ after 6 months on the drug. Standard deviations or standard errors were not given, but the inference of significance drawn by Collipp suggests that deviation from the mean was exceedingly small. Collipp showed that mazindol did not alter height gain during the treatment, but there was a significant decrease in weight gain. There was a significant increase in glutathione peroxidase (GSHPx) concentrations in blood during mazindol treatment. GSHPx is a selenium dependant enzyme which is responsible for removing potentially harmful lipid peroxidation products, and selenium deficiency has been shown to cause muscle disease in animals, ${ }^{16}$ and a cardiomyopathy in humans. ${ }^{23}$ Selenium has been suggested as a therapeutic agent on the basis that muscle damage in the dystrophies may be related to increased lipid peroxidation, ${ }^{24}$ although there is no convincing evidence that supplementation alters the course of muscle wasting in DMD. ${ }^{2526} \mathrm{~A}$ study of selenium metabolism carried out in our Muscle Research Centre in adults with muscular dystrophy and healthy controls has shown that additional dietary selenium can lead to an increase in plasma, but not red cell or muscle GSHPx activity (Jackson, Coakley, Stokes, Oster and Edwards, 1988, unpublished data). Our results suggest that not only does selenium supplementation not alter tissue
Coakley, Moorcraft, Hipkin, Smith, Griffiths, Edwards

GSHPx activity but mazindol has no effect either, and is unlikely therefore to protect against lipid peroxidation induced damage. ${ }^{24}$

There is a discrepancy between the various studies of mazindol in terms of its effect on GH, but this study provides evidence, supported by $\mathrm{Zatz}^{2}$ and Collipp, ${ }^{3}$ that the major effect is on weight gain rather than height gain. The reason for the discrepancy in the GH data may reflect our use of modern methods of measuring GH secretion based on the use of the specific releasing factor and on the physiological secretion, both of which provide reliable results. ${ }^{2728}$

It is possible that mazindol, a potent cerebral dopamine uptake inhibitor, ${ }^{29}$ interferes at a pharmacological level with tests of GH release which require the stimulation of dopaminergic pathways.

Trials of GH inhibitors in muscular dystrophy may be warranted, but on the basis of our results we could not recommend mazindol. It may have an important role in the treatment of the obese patient with muscular dystrophy, although in view of the adverse effects we feel that it should be used with caution in young boys.

A discussion of the ethical problems raised by the deliberate inhibition of growth, such that boys with DMD are further burdened with the problems associated with short stature, is beyond the scope of this article. We feel that functional improvement in muscle performance would have to be striking before growth suppression could be seriously entertained as a possible "treatment".

The authors thank the Muscular Dystrophy Group of Great Britain and Northern Ireland for generous financial support, Professor F Harris, Professor of Child Health, University of Liverpool for advice in the early planning of this study, Miss $\mathrm{H}$ Downey and Mrs B Aycom for assistance during the study and Dr G R Kennedy from Sandoz Ltd for providing the mazindol used in this study. We also thank Dr J R Roberts for allowing us to study patients under his care and Dr M J Jackson for measuring muscle glutathione peroxidase activity. Miss L Nichol kindly typed the manuscript.

\section{References}

1 Smith PEM, Calverley PMA, Edwards RHT, Evans GA, Campbell EJM. Practical problems in the respiratory care of patients with muscular dystrophy. N Engl J Med 1987;316:1197-205.

2 Zatz M, Betti RTB, Frota-Pessoa O. Treatment of Duchenne muscular dystrophy with growth hormone inhibitors. Am J Med Genet 1986;24:549-66.

3 Collipp PJ, Kelemen J, Chen SY, Castro-Magana M, Angulo M, Derenoncourt A. Growth hormone inhibition causes increased selenium levels in Duchenne muscular dystrophy: a possible new approach to therapy. J Med Genet 1984;21:254-6.

4 Mazindol Data Sheet 1987, Sandoz Pharmaceuticals.

5 Chyatte SB, Rudman D, Patterson JH, Gerron GG, O'Beirne I, Barlow J, Jordan A, Shavin JS. Human growth hormone and 
estrogens in boys with Duchenne muscular dystrophy. Arch Phys Med Rehab 1973;54:248-53.

6 Zatz M, Betti RTB. Benign Duchenne muscular dystrophy in a patient with growth hormone deficiency: a five years follow up. Am J Med Genet 1986;24:567-72.

7 Totsuka T, Watanabe K, Kiyono S. Masking of a dystrophic process in genotypically dystrophic dwarf mice. Proc Japan Acad 1981;57:109-13.

8 Collipp PJ, Gupta KB, Amin S, Maddaiah VT, Chen SY. Effects of mazindol on growth and growth hormone. Pediatr Res 1977;11:424.

9 Baritussio A, Enzi G, Rigon G, Molinari M, Inelmen EM, Crepaldi G. Effect of anorexiant drugs on growth hormone secretion in obese children. Pharmacol Res Comm 1978;10: 529-40.

10 Sekiya K, Okajima T, Kato K, Ibayashi H. Acute effects of mazindol on the secretion of ACTH, B-lipotropin, B-endorphin and cortisol in man. Endocr Jap 1984;31:523-8.

11 Moxley RT, Brooke MH, Fenichel GM, et al. Clinical Investigation in Duchenne Dystrophy. VI. Double-Blind Controlled Trial of Nifedipine. Muscle Nerve 1987;10:22-33.

12 Angelini C, Baron C, Bejato L, et al. Italian multicentre trials in Duchenne muscular dystrophy III: Results of fructose diet and calcium antagonists. In: Carraro U, Angelini C, eds. Cell Biology and Clinical Management in Functional Electrostimulation of Neurones and Muscles. Padova: Cleup Editore, 235-9.

13 Edwards RHT, Coakley JH, Stokes M, Wagenmakers AJM, Griffiths RD, Jackson MJ. A tissue pharmacology approach to therapeutic trials in muscular dystrophy. Muscle Nerve 1986;9:270.

14 Davis JC, Hipkin LJ. Clinical Endocrine Pathology, Oxford: Blackwell Scientific Publications, 18-19.

15 Dietrichson P, Coakley J, Smith PEM et al. Conchotome and needle percutaneous biopsy of skeletal muscle. J Neurol Neurosurg Psychiatry 1987;50:1461-7.

16 Subcommittee on Selenium, Committee on Animal Nutrition: Selenium in Nutrition. Washington DC: National Academy of Sciences, 1971.

17 Beutler E, Blume KG, Kaplan JC, Lohr GW, Ramot B, Valentine
WN. International Committee for Standardisation in Haematology: Recommended methods for red-cell enzyme analysis. Br J Haematol 1977;35:331-7.

18 Belchetz PE, Weldon SF, Davis JC, Diver MJ, Smith CS, Harris F. Potential uses of human pancreatic growth hormone-releasing factor 1-44 amide. Clin Endocrinol 1984;21:201-8.

19 Dubowitz V. Muscle Disorders of Childhood. London. WB Saunders, 1978:30-32.

20 Gillis D, Wengrower D, Witztum MD, Leitersdorf E. Fenfluramine and mazindol: acute reversible cardiomyopathy associated with their use. Int J Psychiat Med 1985;15:197-200.

21 Edwards RHT, Round JM, Jackson MJ, Griffiths RD, Lilburn MF. Weight reduction in boys with muscular dystrophy. Dev Med Child Neurol 1974;26:384-90.

22 The Health Services Human Growth Hormone Committee. Comparison of the intravenous insulin and oral clonidine tolerance tests for growth hormone secretion. Arch Dis Child 1981;56:852-4.

23 Keshan Disease Research Group of the Chinese Academy of Medical Sciences. Observations on effect of sodium selenite in prevention of Keshan disease. Chin Med J 1979;92:471-6.

24 Jackson MJ, Jones DA, Edwards RHT. Techniques for studying free radical damage in muscular dystrophy. Medical Biology 1984;22:135-8.

25 Gamstorp I, Gustavson K-H, Hellstrom O, Nordgren B. A trial of selenium and vitamin $\mathrm{E}$ in boys with muscular dystrophy. $J C$ Child Neurol 1986;1:211-4.

26 Gebre-Medhin M, Gustavson K-H, Gamstrop I, Plantin L-O. Selenium supplementation in X-linked muscular dystrophy. Acta Paediatr Scand 1985;74:886-90.

27 Grossman A, Savage MO, Besser GM. Growth hormone releasing hormone. Clin Endocr Metab 1986;15:607-27.

28 King JM, Price DA. Sleep-induced growth hormone releaseevaluation of a simple test for clinical use. Arch Dis Child 1983;58:220-2.

29 Heikkila RE, Cabbat FS, Manzino L, Babington RG, Houlihan WJ. Unexpected differences between mazindol and its homologs on biochemical and behavioural responses. J Pharmacol Exp Ther 1981;217:745-9. 